\title{
Composition's effect of Origanum Syriacum essential oils in the antimicrobial activities for the treatment of denture stomatitis
}

\author{
Loubna Shamseddine $^{1}\left[\right.$ (I) Jose Johann Chidiac $^{1}$
}

Received: 24 April 2020 / Accepted: 10 August 2020 / Published online: 17 August 2020

(c) The Society of The Nippon Dental University 2020

\begin{abstract}
This research has several purposes: First to assess the bacterial and fungal minimum inhibitory concentration of Origanum Syriacum essential oil. Second to quantify its bactericidal and fungicidal minimal concentration against $S$. aureus, S. mutans, and C. albicans found in denture stomatitis. The third purpose is to look at the influence of three different soils (Annaya, Bhanin and Michrif) on the essential oils composition. Three essential oils were extracted by hydro-distillation from three different Origanum Syriacum plant origins. Bioassays were conducted using a broth microdilution methods. Gas Chromatography analysis was used to calculate the abundance of most components in each essential oil. Post hoc tests assessed antimicrobial effects between ecotypes while Pearson's test correlated the different components and their antimicrobial efficiency $(\alpha<0.05)$. All tested essential oils were efficient against all microorganisms. Origanum Syriacum essential oils derived from Annaya and Bhanin soils showed a superior antimicrobial activity compared to the Michrif one. The most abundant component and most efficient among all essential oils constituents was carvacrol. It can be concluded that Origanum Syriacum essential oils have an antimicrobial activity, which depends on the ecotype, its origin and its composition. They might be used to start a clinical trial for the treatment of denture stomatitis.
\end{abstract}

Keywords Denture stomatitis · Origanum syriacum oil · Candida albicans $\cdot$ Streptococcus mutans $\cdot$ Staphylococcus aureus

\section{Introduction}

Denture stomatitis (DS) is a mucosal disorder affecting complete denture (CD) wearers [1]. Its progression is affected by the association of fungal and bacterial infections [2,3]. C. albicans exhibits a tendency to adhere to dentures with a colonization progression up to 78\% [4]. The commonest and highest bacteria isolated on CD wearers are Staphylococcus aureus (S. aureus) with a colonization of up to $66.7 \%$ and Streptococcus mutans (S. mutans) up to 73.3\% [5]. Although various medications are used to treat DS, such as nystatin and miconazole, in a systemic or topic induction [6] but do not prevent the recolonization of bacteria and candida in $\mathrm{CD}$ wearers with poor oral hygiene [7, 8]. A wide range of chemical disinfectants are recommended as decontaminants

Loubna Shamseddine

drloubna1@hotmail.com; lchamseddine@ul.edu.lb

Jose Johann Chidiac

jchidiac@ul.edu.lb

1 Faculty of Dental Medicine, Department of Prosthodontics, Lebanese University, Beirut, Hadat, Lebanon or cleansers of dentures [9]. Unfortunately, these chemical solutions can alter the physical and mechanical properties of acrylic denture bases [10].

Essential oils (EOs) derived from leaves, flowers, roots, stems, seeds or fruits of several plant families, can be a natural source of antimicrobial agents. They stimulated searchers as a natural alternative therapeutic treatment in dental diseases [11]. Recognized as safe, they are used as natural food preservatives for their antimicrobial and antioxidant activities [12]. A certain number of EOs have been reported to display antibacterial, antifungal or anti-inflammatory properties against oral pathogens $[11,13]$. EO against $\mathrm{G}+$ microbial strains (less rigid membrane) has a higher effectiveness when compared to the $\mathrm{G}-$ ones [14-16]. However, this activity is strongly affected by their composition [14, 16-18]. In fact, depending on the composition and location of their functional groups, EOs damage cells differently: either by changing the structure and function of the membrane or by penetrating and interfering with the cell metabolism causing its death [19].

Factors affecting the qualitative and quantitative chemical composition of EO are multiple: Use of extracts from 
cultivated or wild plants [20, 21], harvest period time (before/after flowering, flowering stage) [22], harvest and cultivation site (altitude) [23], location of extracted flowers/ leaves [24], environment climate [24], and extraction mode [25]. Origanum syriacum EO (Os-O) is extracted from Oregano (Origanum spp, family of Lamiacae), a plant characterized by a broad morphological and chemical variety [26]. When comparing several EOs (clove, coriander, cinnamon, thyme, mint, rosemary, mustard, or sage), Oregano's EO ranks among the highest antibacterial efficiency [12].

In the Lebanon, Os-O has two main chemo-types: Thymol and carvacrol. In the Os-O extracted from lebanese plants, the amounts of thymol and carvacrol range between $2.3 \%$ and $74.4 \%$ for thymol $[21,27]$, and $17.6 \%$ and $78.4 \%$ for carvacrol $[28,29]$. The high contents of these phenolic oxygenated monoterpenes in the Lamiaceae family confer to this EO a strong and powerful antimicrobial capacity [27, 30]. The mixture of components, thus, induces a synergetic interaction [17]. This synergetic antimicrobial effect against at least $S$. aureus and $C$. albicans has been demonstrated by the accumulation of active compounds in blended $\mathrm{EO}$ with different ratio having individual major constituents [31, 32].

In denture relining procedures, carvacrol has been incorporated into the soft liner material for its antibacterial and antibiofilm activities [33]. Usually, the clinical application of EOs is limited to its antiseptic use in dentate patients. It is found in mouthwash form, as a combination of different organic compounds produced from many species plant (e.g. Listerine ${ }^{\circledR}$ ) [34]. EO is used to decrease stomatitis in denture wearers $[7,35]$. Studies demonstrate that the Lebanese variety of Os-O exhibits a good antimicrobial activity against two of the most bacterial species that adhere to dentures: $S$. aureus and C. albicans [27,
36]. No information on the effectiveness of Os-O against $S$. mutans is currently available.

The main purposes of this study are: To determine the bacterial and fungal minimum inhibitory concentration (MIC, MIFC, respectively) and bactericidal and fungicidal minimum concentrations (MBC, MFC, respectively) of Os-O against $S$. aureus, S. mutans, and $C$. albicans in DS, to study the difference of composition between three different Os-O extracted from wild Lebanese plant ecotypes and finally to determine the most antimicrobial compound in each ecotype.

The null hypothesis is that there is no difference between the different EOs in relation to their antibacterial and antifungal effects, as well as for their chemical composition efficiency.

\section{Materials and methods}

\section{Plant source}

Three ecotypes of wild Os plants differentiated by their area of origin, inflorescence, compaction and shape of leaf were harvested during the same period (Table 1). Their aerial parts were brought by cutting from three different Lebanese territories and were cultivated in one single location (Lebaa station of the Lebanese Agriculture Research Institute: LARI; $360 \mathrm{~m}$ altitude). They were left growing wild in the same soil and same climatic conditions. Three EOs used in this study were produced from these plants. Collections of data are reported in Table 1.

Table 1 Plants collection, location of extracts and botanical characteristics of $O s$ plants ecotypes

\begin{tabular}{|c|c|c|c|c|c|c|c|c|}
\hline \multirow{2}{*}{\multicolumn{2}{|c|}{ Plants used }} & \multirow{2}{*}{\multicolumn{4}{|c|}{$\frac{\text { Collection data }}{\text { Studied origin }}$}} & \multicolumn{3}{|c|}{ Botanical characteristics } \\
\hline & & & & & & \multirow{2}{*}{$\begin{array}{l}\text { Visual differen- } \\
\text { tiations }\end{array}$} & \multicolumn{2}{|c|}{ Similar characteristics } \\
\hline Plant name & $\begin{array}{l}\text { Location of } \\
\text { extract }\end{array}$ & $\begin{array}{l}\text { Harvesting } \\
\text { period }\end{array}$ & $\begin{array}{l}\text { Region gover- } \\
\text { norate }\end{array}$ & District & Altitude & & & \\
\hline \multirow[t]{3}{*}{$\begin{array}{l}\text { Origanum syri- } \\
\text { acum Os }\end{array}$} & \multirow[t]{3}{*}{ Flowering top } & \multirow[t]{3}{*}{ Spring (April) } & Bhanin North & $\begin{array}{r}\text { El-Minye } \\
\text { Zgharta }\end{array}$ & $63 \mathrm{~m}$ & $\begin{array}{l}\text { Elliptic leaf } \\
\text { shape non- } \\
\text { compact } \\
\text { inflorescence }\end{array}$ & $\begin{array}{l}\text { Growth habit } \\
\text { Leaf apex }\end{array}$ & $\begin{array}{l}\text { Ascendant } \\
\text { Acute }\end{array}$ \\
\hline & & & Annaya North & Jbeil & $1000 \mathrm{~m}$ & $\begin{array}{l}\text { Ovate leaf } \\
\text { shape semi- } \\
\text { compact } \\
\text { inflorescence }\end{array}$ & $\begin{array}{l}\text { Corolla color } \\
\text { Leaf color }\end{array}$ & $\begin{array}{l}\text { White } \\
\text { Green }\end{array}$ \\
\hline & & & Mount Lebanon & Al-Shouf & $397 \mathrm{~m}$ & $\begin{array}{l}\text { Ovate leaf } \\
\text { shape non- } \\
\text { compact } \\
\text { inflorescence }\end{array}$ & $\begin{array}{l}\text { Stem color } \\
\text { Leaf hairs }\end{array}$ & $\begin{array}{l}\text { Brown } \\
\text { Dense }\end{array}$ \\
\hline
\end{tabular}




\section{Extract preparation}

The extraction of EOs was performed following the quality standards of European Pharmacopoeia by hydro-distillation in a Clevenger-type system, for $3 \mathrm{~h}$. The yields ( $/ \mathrm{w}$, relative to fresh weight material) produced from fresh weight of the flowering tops of Os are variable according to the plant origin (1\% from Mishrif, $1.2 \%$ from Bhanin and $1.7 \%$ from Annaya). Oils were stored in sealed and labeled glass vials in a dark room at room temperature until use.

\section{Preparation of microbial strains}

All strains (S. aureus ATCC 25,923, S. mutans UA159, and C. albicans ATCC 10,231) used in the study were provided by the Microbiology Department of Faculty of Sciences at the Lebanese University, Hadath, Lebanon. Bacterial pre-cultures and yeast pre-cultures were prepared and adjusted to an optical density (OD600) of 0.5.

\section{Antimicrobial testing (Screening)}

The antibacterial and antifungal activities of all EOs were carried out in vitro against the most microorganism adherent to complete dentures ( $S$. aureus, S. mutans and C. albicans).

A standardized method was used to determine the bacterial MICs and MBCs as well as fungal MIFC and MFC of each EO ecotype using the microdilution technique following the Clinical and Laboratory Standards Institute guidelines. Microdilutions were realized in Mueller-Hinton nutrient broth (MHB) for bacteria and Tryptone Soya broth (TSB) for candida. $250 \mu \mathrm{L}$ of pure EO solutions was mixed with $250 \mu \mathrm{L}$ of DMSO (10\%) to obtain a homogenous solution of EO of 50\% from the beginning and for each extract. Then, serial two-fold dilutions of EO (50\%) in MHB (for bacteria) and TSB (for Candida) were prepared in a 96-well plate ( $90 \mu \mathrm{L}$ per well). Control wells with no EO added were used as a positive growth control. A diluted bacterial suspension was added to each well to give a final concentration of $5 \times 105 \mathrm{CFU} / \mathrm{mL}$. Wells with only DMSO without bacteria added were used as a negative growth control. The microplates were incubated for $24 \mathrm{~h}$ at $37{ }^{\circ} \mathrm{C}$. MICs were identified by the absence of visible bacterial growth (clear wells) at the minimal dilution when compared to positive and negative control groups. Wells showing no visible growth were placed on Muller-Hinton agar. They were evaluated after overnight incubation at $37^{\circ} \mathrm{C}$. The MBC was defined as the lowest concentration of EO producing clear wells. Triplicate independent tests were conducted for each assay.

\section{Gas chromatography analysis}

The abundance of the seven individual molecular most frequent components reported in the literature for each tested EO was assessed [21, 27-29, 36], in a standardized setting of a gas chromatograph apparatus (Shimadzu Corp., GC-2010 Plus); The injector temperature was set at $250{ }^{\circ} \mathrm{C}$, and linear velocity at $36.5 \mathrm{~cm} / \mathrm{s}$. The column was initially set at $60{ }^{\circ} \mathrm{C}$ and gradually increased to $210{ }^{\circ} \mathrm{C}$ with rate of $3{ }^{\circ} \mathrm{C} / \mathrm{min}$. The flame ionization detection was set at $250{ }^{\circ} \mathrm{C}$. Each tested EO had similar preparation steps. After mixing $0.1 \mathrm{~g}$ of EO with $2 \mathrm{ml}$ of hexane and manually agitating for $2 \mathrm{~s}, 0.2 \mathrm{ml}$ of potassium hydroxide methanol was added and agitated in vortex for $2 \mathrm{~min}$ followed by $5 \mathrm{~min}$ of holding period for the phase separation. Then, $975 \mu \mathrm{l}$ was withdrawn from the organic phase (upper) to which $25 \mu \mathrm{l}$ of monodecanoate was injected. Each mixture was then injected into the carrier gas (Hydrogen) with a flow rate at $0.1 \mathrm{ml} / \mathrm{min}$, through the fused-silica capillary columns (DB-5 MS, PN $122-5031$ having $30 \mathrm{~m}$ in length, $0.25 \mathrm{~mm}$ of inner diameter, and $0.1 \mu \mathrm{m}$ in thickness). A detector of boiling temperature, generated an electronic signal that was converted to a chromatogram for each molecule. Molecules with low boiling point, were eluted faster at low temperature. Determination and abundance of molecules were identified according to standard and retention time.

\section{Statistical analyses}

All data were analyzed using statistical software (XLSTAT®-BIOMED, Addinsoft, USA). When necessary, data were log-transformed to improve normality and variance homogeneity of residues. Analyses of variance for ecotype and microorganism were analyzed by a two-way ANOVA (Fisher; $P<0.001$ ). Post hoc tests were performed using the Tukey's method to assess differences on antimicrobial effects between ecotypes. Pearson's test was used for correlation tests. The level of significance was set at $5 \%$.

\section{Results}

In general, results confirm the importance of the origin of plants, their respective ecotype and their respective chemical composition. In particular, all EOs have an effect on all tested microorganisms and their efficiency varied depending on the ecotype and the region where plants were collected (Table 2).

For bacteriostatic and fungi-static activities of the three tested EOs against the three microbes, significant lower MIC activity against $S$. aureus was found in the EO derived from Michrif (3.132) compared to those derived from Annaya and Bhannin (0.781). MIC activity of Os-O against $S$. mutans 
Table 2 Analyses of variance with $F$ values

\begin{tabular}{|c|c|c|c|c|c|c|}
\hline \multicolumn{3}{|c|}{ Two-way ANOVA test (Fisher) } & \multicolumn{4}{|c|}{ Post hoc test (Tukey) } \\
\hline & $\mathrm{MIC} / \mathrm{MIFC}$ & $\mathrm{MBC} / \mathrm{MFC}$ & EO sources & Strain & $\mathrm{MIC} / \mathrm{MIFC}$ & $\mathrm{MBC} / \mathrm{MFC}$ \\
\hline EO sources & $272,079 * * *$ & $14,145 * * *$ & Bhanin & $\begin{array}{l}\text { S. aureus } \\
\text { C. albicans } \\
\text { S. mutans }\end{array}$ & $\begin{array}{l}0.781 \mathrm{e} \\
0.195 \mathrm{~d} \\
0.049 \mathrm{~b}\end{array}$ & $\begin{array}{l}1.563 \mathrm{c} \\
0.195 \mathrm{a} \\
0.195 \mathrm{a}\end{array}$ \\
\hline Strains & $36,736 * * *$ & $3122 * * *$ & Michrif & $\begin{array}{l}\text { S. aureus } \\
\text { C. albicans } \\
\text { S. mutans }\end{array}$ & $\begin{array}{l}3.132 \mathrm{~g} \\
1.563 \mathrm{f} \\
3.132 \mathrm{~g}\end{array}$ & $\begin{array}{l}6.317 \mathrm{e} \\
3.132 \mathrm{~d} \\
3.132 \mathrm{~d}\end{array}$ \\
\hline Source $x$ Strain & $11,386 * * *$ & $571 * * *$ & Annaya & $\begin{array}{l}\text { S. aureus } \\
\text { C. albicans } \\
\text { S. mutans }\end{array}$ & $\begin{array}{l}0.781 \mathrm{e} \\
0.024 \mathrm{a} \\
0.098 \mathrm{c}\end{array}$ & $\begin{array}{l}0.781 \mathrm{~b} \\
0.098 \mathrm{a} \\
0.098 \mathrm{a}\end{array}$ \\
\hline
\end{tabular}

Significant level: $* * * p<0.001$ and bacteriostatic, bactericidal, fungistatic, and fungicidal means of 3 replicates given in \% for ecotypes used in the study. "a" to "g" letters indicate statistical difference $(p<0.05$, Tukey test) was found significantly superior by order of efficiency when derived from Bhannin (0.049), Annaya (0.098), Michrif (3.132), respectively. In relation to MIFC activity against C. albicans, it was found significantly superior for the EO derived from Annaya (0.024), Bhannin (0.195) and Michrif (1.563), respectively.

As for bactericidal and fungicidal activities, the effect against $S$. aureus, $S$. mutans, and $C$. albicans varied depending on the ecotype plants and the region origin. MBC activity against $S$. aureus was found to be significantly superior in EO derived from Annaya (0.781), Bhannin (1.563) and Michrif (6.317), respectively. MBC activity against $S$. mutans, was found significantly superior in $\mathrm{EO}$ derived from Annaya and Bhannin (0.098 and 0.195, respectively, with no significant differences) followed by Michrif (3.132). Similarly, a significantly superior efficiency of EO derived from Annaya and Bhannin (0.098 and 0.195, respectively, with no significant differences) followed by Michrif (3.132) against C. albicans. The Michrif ecotype provides the least effect against all other strains. Statistically significant differences for antimicrobial effects exist between the tested EOs and are reported in Table 2.

GC analyses led to identify variable relative proportions in most components between EOs (Table 3). The phenolic compounds, thymol and carvacrol, are found in high proportions in all three Os ecotypes with carvacrol having the highest proportion in all specimens. A negative strong correlation was found between carvacrol composition and MICs with MIFC and MBCs with MFC $\left(R^{2}=0.818\right.$ and 0.7714 , respectively). Another weaker negative correlation was also found between thymol and MICs with MIFC and MBCs with MFC ( $R^{2}=0.4962$ and 0.5117 , respectively) and between thymoquinone and MICs with MIFC and MBCs with MFC ( $R^{2}=0.4297$ and 0.4506, respectively) (Figs. 1 and 2).

\section{Discussion}

In the field of dentistry, rinses from EOs or incorporated into mouthwashes as home-care routine could be used to treat recurrent aphthous ulcerations, to control post-surgical periodontal infections, for implant maintenance, and for dental caries or gingivitis prevention. EOs could be applicable as an antiviral (herpes, HIV1) and disinfectant for the dental unit waterlines or aerosols. In addition, mouthwashes containing EO could be used to reduce viral contamination from the oral environment by rinsing at least $30 \mathrm{~min}$ [37-40] However, all these reviews were published in the pre-Covid-19 pandemic and need to be updated with no data available for the moment.

Many species of plants, such as Peppermint, Cinnamon, Lemon, Clove and Tee tree, produce EOs that have potential uses as preventive or therapeutic against four common oral pathogens ( $S$. aureus, Enterococcus faecalis, E. coli, and C. albicans). Each of these EOs is effective against at least

Table 3 Relative proportion $(\mathrm{ppm}=\mathrm{mg} / \mathrm{l}$ ) of the individual major constituents of the three EOs

\begin{tabular}{rrrrrrrrr}
\hline & & Carvacrol & Thymol & Thymoquinone & $P$-Isopropyltoluene & Linalool & $\alpha$-Terpineol & $\gamma$-Terpinene \\
\hline Os-O & Annaya & $\mathbf{1 9 , 9 7 4 . 0}$ & $\mathbf{3 3 0 . 1}$ & $\mathbf{1 6 9 . 4}$ & 148.4 & 26.9 & 89.4 & 59.7 \\
& Bhanin & $\mathbf{1 8 , 5 2 4 . 0}$ & $\mathbf{1 2 5 . 7}$ & $\mathbf{9 6 . 0}$ & 508.6 & 107.0 & 399.3 & 962.2 \\
& Michrif & $\mathbf{2 0 9 7 . 1}$ & $\mathbf{1 5 . 8}$ & $\mathbf{6 8 . 1}$ & 1175.8 & 136.6 & 393.6 & 714.6 \\
\hline
\end{tabular}

In bold: The most active compounds 

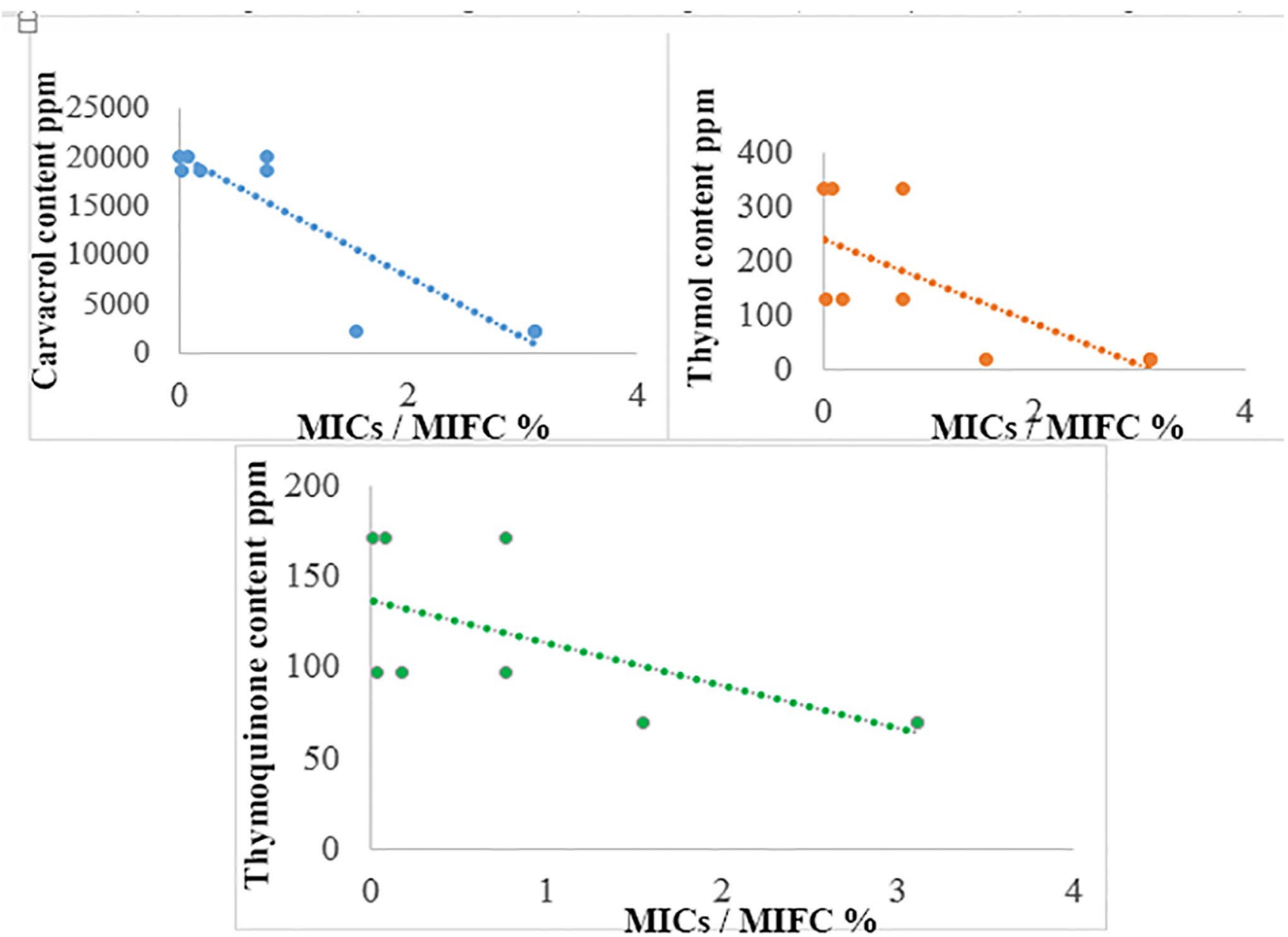

Fig. 1 Pearson correlation test between carvacrol, thymol, and thymoquinone content and MICs/MIFC $\left(R^{2}=\right.$ coefficients of determination). Equations of regression: Carvacrol: $y=-6172.5 x+20,213$

one of the microbes responsible for oral mucosal disorders associated to complete denture wear [11].

In this study, Os-O (especially from Annaya and Bhannin) was found effective on the three microbes simultaneously. The practical use would be to include it in denture cleaning agents, thus, decreasing the effective time of immersion or exclude the need of a combination of EOs.

Os-O was generally found to be nontoxic and a cancersuppressor agent [38, 42, 43]. Incorporated in the mouthwash, altered taste, reversible local reaction, and rare allergic reaction have been reported [44]. Despite that and in some cases, erythema and sloughed-off epithelial cells were seen as adverse reactions in the oral mucosa, [45] but did not show any sign of toxicity on human lymphocytes (in vitro study), neither any DNA damage, cytokinetic defects, proliferative potential or cell death (in vivo studies) [44, 46].

One of the disadvantages of Origanum syriacum essential oils is the small quantity of EO derived from flowering tops of the plants (yields that are variable with the ecotype ranged
$\left(R^{2}=0.818\right)$; Thymol: $\mathrm{y}=-77.225 \mathrm{x}+240.79\left(R^{2}=0.4962\right)$; Thymoquinone: $\mathrm{y}=-23.574 \mathrm{x}+136.68\left(R^{2}=0.4297\right)$

between $1 \%$ to $1.7 \%$ ) making it expensive in producing EO for commercial application.

The first hypothesis stating that EOs would have different antimicrobial effects on most frequent germs adhering to dentures was accepted. The second hypothesis that EOs would have different chemical composition was also accepted.

A major finding from this study showed that the three OS-Os have different antimicrobial efficiency against most strains related to DS with a higher efficiency associated to carvacrol content. Another finding was that different plant ecotypes brought from different geographical locations but grown in similar climate and soil conditions might produce EOs with variable composition and antimicrobial efficiency.

The efficiency and chemical composition of various plant part of Os-O can be evaluated in different ways. Efficiency of EOs can be tested in measuring the colony diameter of mycelial growth into petri dishes [21], in using an agar disc diffusion [26] and by broth microdilution [27]. 


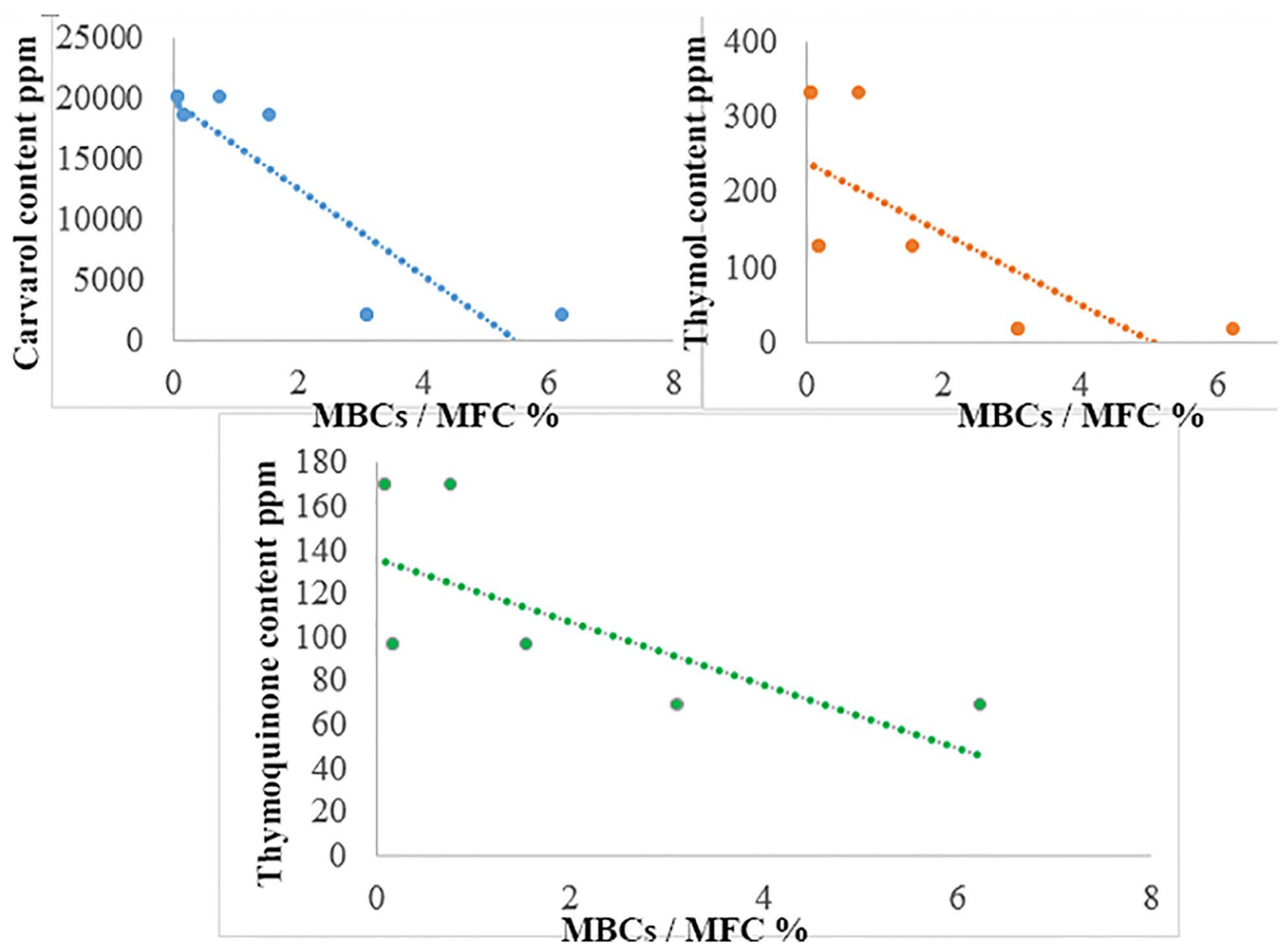

Fig. 2 Pearson correlation test between carvacrol, thymol, and thymoquinone content and MBCs/MFC $\left(R^{2}=\right.$ coefficients of determination). Equations of regression: Carvacrol: $y=-3595.9 x+19,696$

Visual turbidity evaluation is another method of assessing the microbial growth using the microdilution technique $[27,47]$. Results of EOs concentration were expressed following either the mass of oil to the volume of medium solution ratio $(\mu \mathrm{g} / \mathrm{ml}$, or $\mathrm{mg} / \mathrm{ml})[27,36]$ or the oil volume to the volume of medium solution ratio $(\mu \mathrm{l} / \mathrm{ml})$ [21]. Another way of writing results can be a percentage of pure EOs into the solution to determine the antibacterial effect [14]. In this study, serial dilutions with a suitable medium in a 96-well plates were realized, a visual assessment of the solution turbidity was applied and the percentage of EOs into the solution determined the concentration.

Numerous studies about the antimicrobial evaluation of Oregano EO, tested individually or in combination with other constituents resulted a wide variability of efficiency $[14,17,21,26,27,32]$. Their findings could be attributed to the differences in extraction mode, soil conditions, harvesting season, geographical location, climatic and growth conditions [41].
$\left(R^{2}=0.7714\right)$; Thymol: $\mathrm{y}=-47.046 \mathrm{x}+237.86\left(R^{2}=0.5117\right)$; Thymoquinone: $\mathrm{y}=-14.483 \mathrm{x}+136\left(R^{2}=0.4506\right)$

The study findings confirmed that microorganisms have different sensitivities to all three EOs depending on their ingredients composition. This is in line with other studies [14-17].

Carvacrol is probably one of the major components related to the efficiency of these EOs as shown by the negative correlation between carvacrol minimal concentration and antimicrobial efficiency (Figs. 1 and 2). The "Annaya" ecotype had the highest content of carvacrol (19,974 ppm) followed, respectively, by "Bhanin" (18,524 ppm) and "Michrif" (2097 ppm) (Table 3). The present findings confirmed that carvacrol is the major component of EO from oregano $[14,18]$. Its mode of action alters the membrane permeability for cations $(\mathrm{H}+, \mathrm{K}+)$ in $\mathrm{G}+$ bacteria [48]. The content of thymol found could also enhance the activity of the EO by disruption of the cellular membrane, inhibition the ATPase activity, and release of intracellular ATP and other constituents [49]. Thymoquinone in our study was correlated to the antimicrobial efficiency. This is in line with 
other study preventing adhesion and proliferation of C. albicans on dentures [50]. The lowest efficiency for both MIC/ MIFC and MBC/MFC on all tested strains was found in the "Michrif" ecotype. When comparing the "Annaya" and the "Bhanin" ecotypes, a similar MIC activity on S. aureus was found between them with a superior antifungal activity for "Annaya" against $C$. albicans, and a superior antibacterial activity of "Bhanin" ecotype on S. mutans. As for the MBC values, they were similar for $C$. albicans and $S$. mutans with a higher effectiveness of the "Annaya" ecotype on S. aureus. (Table 2).

While bactericidal effect against $S$. aureus and fungicidal effects against $C$. albicans of Os were not reported in the literature, this study demonstrated that significant mean concentrations of $1.563 \%, 0.781 \%$, and $6.317 \%$ of EOs from "Bhanin", "Annaya", and "Mishrif", respectively, were effective on S. aureus. Similarly, fungicidal activity was found on C. albicans at the concentration of $0.195 \%, 0.098 \%$, and $3.132 \%$, respectively, with no statistical significance between "Annaya" and "Bhanin" (Table 2).

In addition, according to the abovementioned antimicrobial and bactericidal activities on S. mutans, there is no previous information reported in the literature. The MIC and $\mathrm{MBC}$ mean values significantly varied according to the plant ecotype ("Bhanin": $\mathrm{MIC}=0.049 \% / \mathrm{MBC}=0.195 \%$; "Annaya": MIC and MBC $=0.098 \%$; "Mishrif": MIC and $\mathrm{MBC}=3.132 \%)($ Table 2). Studies demonstrate that a high anti-streptococcal activity is attributed to a high terpenoid metabolites content [51], or to a polyphenolic content of an EO [52]. Carvacrol found in this experiment ranged from $2097.1 \mathrm{ppm}$ to $19,974.0 \mathrm{ppm}$ while thymol ranged from $15.8 \mathrm{ppm}$ to $330.1 \mathrm{ppm}$ (Table 3 ). Both chemicals had a higher content in the "Annaya" EO. The synergetic interaction between the two components [17] would explain the activity against Streptococcus strain, the "Annaya" ecotype having the highest effectiveness.

Whereas, the bacteriostatic effect against $S$. aureus of Os-O has been evaluated by Gendy et al. 2015 and Ibrahim et al. 2012, the study results support previous findings that $S$. aureus is sensitive to Os-O with a variable MIC (range $0.781-3.132 \%$ equivalent to $15.625-62.5 \mu \mathrm{l} / \mathrm{ml}$ dilution in other studies). These values are lower than the ones found by El Gendy et al. (12.5\%) [26] and higher than Ibrahim et al. $(0.2 \mu \mathrm{l} / \mathrm{ml})$ [21]. Comparing Os-O from Lebanese territory, it was found that these ecotypes are efficient against $S$. aureus (MIC values of $128 \mu \mathrm{g} / \mathrm{ml}, 0.4 \mathrm{mg} / \mathrm{ml}$, and $0.2 \mu \mathrm{l} / \mathrm{ml}$ ), and against $C$. albicans (MIFC values of $128 \mu \mathrm{g} / \mathrm{ml}$ and $0.8 \mathrm{mg}$ / ml) $[21,27,36]$.

The higher sensitivity of $C$. albicans against Os-O derived from Annaya and Bhanin origin can be attributed to the carvacrol and thymoquinone proportions found during the GC analysis. This finding confirmed other studies' results showing that various metabolites including carvacrol and thymoquinone provide the antifungal activity to EOs [53].

The tested Os-O contains carvacrol, thymol and thymoquinone in enough proportions to be used for the treatment of DS. In fact, they might reduce the time and concentration of antibiotics needed in the therapeutic approaches.

The variability of results found in other studies could be due to the variability in geographical areas and weather conditions during the growing time that might affect the contents of the active components [41]. This might explain the differences in chemical profiles resulting from differences in harvesting regions. The difference between this study findings and other studies is mainly due to the variations in the composition of each plant ecotype and in the difference of the study design. In the present study, flowering tops of fresh wild plants were used, while others used dry leaves during the flowering period [21], dry aerial part without identifying the period or the location [36] or even before the flowering period [26]. Furthermore, other studies used flowering tops grown at different altitudes and collected in summer [27]. The plant collection in a different season explained the variability in EOs yields ( $\mathrm{v} / \mathrm{w}$ ) obtained by hydro-distillation in this study (between 1.0\% and 1.7\%) and the ones obtained by Khoury et al. $2016(1.3 \%)$ [27].

EOs are used to disinfect dentures in mouthwash form [35], or when its major compound is incorporated into a soft liner [33]. The antimicrobial effectiveness of Os-O on denture materials should be further investigated before its clinical application in immersion form.

\section{Conclusion}

Within the limitations of this study, Origanum syriacum essential oils have an antimicrobial activity against microbial and candida flora found in denture stomatitis. This activity varies according to the ecotype, origin of the plants and the composition of the EOs. The findings of this study show that Os-O can be considered in the treatment of denture stomatitis.

Acknowledgements The authors thank Pr. Jean Habib (Pharmacist researcher, at the faculty of pharmacy-Lebanese University) for his contribution in the extraction of essential oil, Pr. Kassem Hamze (Biologist, Researcher at the platform of microbiology laboratory in the Faculty of Sciences- Lebanese University) for his assistance in the microbiological assays, Dr. Abdel Kader El Hajj (Head of Lebaa Station at the Lebanese Agriculture Research Institute) for his contribution in plants collection and chemical composition screening and Dr. Ali Kanso for assessing the statistical analysis.

\section{Compliance with ethical standards}

Conflict of interest No conflict of interest declared. 


\section{References}

1. Aoun G, Cassia A. Evaluation of denture-related factors predisposing to denture stomatitis in a Lebanese population. Materia Socio-Medica. 2016;28:392-6.

2. Gendreau L, Loewy ZG. Epidemiology and etiology of denture stomatitis. J Prosthodont. 2011;20:251-60.

3. O'Donnell LE, Robertson D, Nile CJ, Cross LJ, Riggio M, Sherriff A, Bradshaw D, Lambert M, Malcolm J, Buijs MJ, Zaura E, Crielaard W, Brandt BW, Ramage G. The Oral Microbiome of Denture Wearers Is Influenced by Levels of Natural Dentition. PLoS ONE. 2015;10:e0137717.

4. Gauch LMR, Pedrosa SS, Silveira-Gomes F, Esteves RA, Marques-da-Silva SH. Isolation of Candida spp. from denture-related stomatitis in Pará, Brazil. Braz J Microbiol. 2018;49:148-51.

5. Nair VV, Karibasappa GN, Dodamani A, Rashanth VK. Microbial contamination of removable dental prosthesis at different interval of usage: An in vitro study. J Indian Prosthodont Soc. 2016;16:346-51.

6. Budtz-Jorgensen E, Mojon P, Rentsch A, Deslauriers N. Effects of an oral health program on the occurrence of oral candidosis in a long-term care facility. Community Dent Oral Epidemiol. 2000;28:141-9.

7. Pinelli LA, Montandon AA, Corbi SC, Moraes TA, Fais LM. Ricinus communis treatment of denture stomatitis in institutionalised elderly. J Oral Rehabil. 2013;40:375-80.

8. Yarborough A, Cooper L, Duqum I, Mendonça G, McGraw K, Stoner L. Evidence regarding the treatment of denture stomatitis. J Prosthodont. 2016;25:288-301.

9. Basavanna JM, Jujare RH, Varghese RK, Singh VD, Gaurav A. Effects of laboratory disinfecting agents on dimensional stability of three commercially available heat-cured denture acrylic resins in India: An In-Vitro Study. J Clin Diagn Res. 2016;10:27-31.

10. Lohitha K, Prakash M, Gopinadh A, Sai Sankar AJ, Sandeep $\mathrm{CH}$, Sreedevi B. Color stability of heat-cure acrylic resin subjected to simulated short-term immersion in fast-acting denture cleansers. Ann Med Health Sci Res. 2016;6:291-5.

11. Dagli N, Dagli R, Mahmoud RS, Baroudi K. Essential oils, their therapeutic properties, and implication in dentistry: A review. $\mathrm{J}$ Int Soc Prev Community Dent. 2015;5:335-40.

12. Nieto G. Biological activities of three essential oils of the lamiaceae family. Medicines (Basel). 2017;4:63.

13. Takarada K, Kimizuka R, Takahashi N, Honma K, Okuda K, Kato T. A comparison of the anti-bacterial efficacies of essential oils against oral pathogens. Oral Microbiol Immunol. 2004;19:61-4.

14. Man A, Santacroce L, Jacob R, Mare A, Man L. Antimicrobial activity of six essential oils a group of human pathogens: a comparative study. Pathogens. 2019;8:15.

15. Trombetta D, Castelli F, Sarpietro MG, Venuti V, Cristani M, Daniele C, Saija A, Mazzanti G, Bisignano G. Mechanisms of antibacterial action of three monoterpenes. Antimicrob Agents Chemother. 2005;49:2474-8.

16. Huang DF, Xu JG, Liu JX, Zhang H, Hu QP. Chemical constituents, antibacterial activity and mechanism of action of the essential oil from Cinnamomum cassia bark against four food related bacteria. Microbiology. 2014;83:357-65.

17. Dorman HJ, Deans SG. Antimicrobial agents from plants: Antibacterial activity of plant volatile oils. J Appl Microbiol. 2000;88:308-16.

18. Tongnuanchan P, Benjakul S. Essential oils: extraction, bioactivities, and their uses for food preservation. J Food Sci. 2014;79:1231-49.
19. Nazzaro F, Fratianni F, De Martino L, Coppola R, De Feo V. Effect of essential oils on pathogenic bacteria. Pharmaceuticals (Basel). 2013;6:1451-74.

20. Teymouri M, Alizadeh A. Chemical composition and antimicrobial activity of the essential oil of Mentha mozaffarianii Jamzad growing wild and cultivated in Iran. Nat Prod Res. 2018;32:1320-3.

21. Ibrahim L, Karaky M, Ayoub P, El Ajouz N, Ibrahim S. Chemical composition and antimicrobial activities of essential oil and its components from Lebanese Origanum syriacum L. J Essent Oil Res. 2012;24:339-45.

22. Zein S, Awada S, Rachidi S, Hajj A, Krivoruschko E, Kanaan H. Chemical analysis of essential oil from Lebanese wild and cultivated Origanum syriacum (Lamiaceae) before and after flowering. J Med Plants Res. 2011;5:379-87.

23. Tsasi G, Mailis T, Daskalaki A, Sakadani E, Razis P, Samaras Y, Skaltsa $\mathrm{H}$. The effect of harvesting on the composition of essential oils from five varieties of Ocimum basilicum L. cultivated in the island of Kefalonia, Greece. Plants (Basel). 2017;6:41.

24. Angioni A, Barra A, Coroneo V, Dessi S, Cabras P. Chemical composition, seasonal variability, and antifungal activity of Lavandula stoechas essential oils from stem/leaves and flowers. J Agric Food Chem. 2006;54:4364-70.

25. Taban A, Saharkhiz MJ, Niakousari M. Sweet bay (Laurus nobilis L.) essential oil and its chemical composition, antioxidant activity and leaf micromorphology under different extraction methods. Sustain Chem Pharm. 2018;9:12-8.

26. El Gendy AN, Leonardi M, Mugnaini L, Bertelloni F, Ebani VV, Nardoni S, Mancianti F, Hendawy S, Omer E, Pistelli L. Chemical composition and antimicrobial activity of essential oil of wild and cultivated Origanum syriacum plants grown in Sinai. Egypt Ind Crops Prod. 2015;67:201-7.

27. Khoury M, Stien D, Eparvier V, Ouaini N, El Beyrouthy M. Report on the medicinal use of eleven Lamiaceae species in Lebanon and rationalization of their antimicrobial potential by examination of the chemical composition and antimicrobial activity of their essential oils. Evid Based Complement Alternat Med. 2016;2547169.

28. Loizzo MR, Menichini F, Conforti F, Tundis R, Bonesi M, Saab AM. Chemical analysis, antioxidant, antiinflammatory and anticholinesterase activities of Origanum ehrenbergii Boiss and Origanum syriacum L. essential oils. Food Chem. 2009;117:174-80.

29. Farhat M, Tóth J, Héthelyi BÉ, Szarka Sz, Czigle Sz. Analysis of the essential oil compounds of origanum syriacum L. Acta Fac Pharm Univ Comen. 2012;59:6-14.

30. Hussain AI, Anwar F, Nigam PS, Sarker S, Moore J, Rao J, Mazumdar A. Antibacterial activity of some Lamiaceae essential oils using resazurin as an indicator of cell growth. LWT Food Sci Technol. 2011;44:1199-206.

31. Tadtong S, Puengseangdee $\mathrm{C}$, Prasertthanawut $\mathrm{S}$, Hongratanaworakit T. Antimicrobial constituents and effects of blended eucalyptus, rosemary, patchouli, pine, and cajuput essential oils. Nat Prod Commun. 2016;11:267-70.

32. Honório VG, Bezerra J, Souza GT, Carvalho RJ, Gomes-Neto NJ, Figueiredo RC, Melo JV, Souza EL, Magnani M. Inhibition of Staphylococcus aureus cocktail using the synergies of oregano and rosemary essential oils or carvacrol and 1,8-cineole. Front Microbiol. 2015;6:1223.

33. Baygar T, Ugur A, Sarac N, Balci U, Ergun G. Functional denture soft liner with antimicrobial and antibiofilm properties. J Dent Sci. 2018;13:213-9.

34. Quintas V, Prada-López I, Prados-Frutos JC, Tomás I. In situ antimicrovial activity on oral biofilm: essential oils vs. 0.2 \% chlorhexidine. Clin Oral Invest. 2018;19:97-107. 
35. Janjic-Pavlovic O, Stancic I, Cicmil S, Stojanovic Z, Lecic J, Elencevski S. The use of essential oils based antiseptic solution in the treatment of denture stomatitis. Serbian Dent J. 2017;64:7-13.

36. Al Hafi M, El Beyrouthy M, Ouaini N, Stien D, Rutledge D, Chaillou S. Chemical Composition and Antimicrobial Activity of Origanum libanoticum, Origanum ehrenbergii, and Origanum syriacum Growing Wild in Lebanon. Chem Biodiver. 2016;13:555-60.

37. Claffey N. Essential oil mouthwashes: a key component in oral health management. J Clin Periodontol. 2003;30:22-4.

38. Yengopal V. Essential oils: some lesser known uses and properties for improved oral health. SADJ. 2004;59:381-4.

39. Araujo MWB, Charles CA, Weinstein RB, McGuire JA, ParikhDas AM, Du Q, Zhang J, Berlin JA, Gunsolley JC. Meta-analysis of the effect of an essential oil-containing mouthrinse on gingivitis and plaque. J Am Dent Assoc. 2015;146:610-22.

40. Meiller TF, Silva A, Ferreira SM, Jabra-Rizk MA, Kelley JI, DePaola LG. Efficacy of listerine antiseptic in reducing viral contamination of saliva. J Clin Periodontol. 2005;32:341-6.

41. Leyva-López N, Gutiérrez-Grijalva EP, Vazquez-Olivo G, Heredia JB. Essential oils of oregano: biological activity beyond their antimicrobial properties. Molecules. 2017;22:989.

42. Al-Kalaldeh JZ, Abu-Dahab R, Afifi FU. Volatile oil composition and antiproliferative activity of Laurus nobilis, Origanum syriacum, Origanum vulgare, and Salvia triloba against human breast adenocarcinoma cells. Nutr Res. 2010;30:271-8.

43. El Babili F, Bouajila J, Souchard JP, Bertrand C, Bellvert F, Fouraste I, Moulis C, Valentin A. Oregano: chemical analysis and evaluation of its antimalarial, antioxidant, and cytotoxic activities. J Food Sci. 2011;76:512-8.

44. Türkez H, Togar B, Arabaci T. Evaluation of genotoxicity after application of Listerine $(\mathrm{R})$ on human lymphocytes by micronucleus and single cell gel electrophoresis assays. Toxicol Ind Health. 2012;28:271-5.

45. Vlachojannis C, Winsauer H, Chrubasik S. Effectiveness and safety of a mouthwash containing essential oil ingredients. Phytother Res. 2013;27:685-91.
46. Ros-Llor I, Lopez-Jornet P. Cytogenetic analysis of oral mucosa cells, induced by chlorhexidine, essential oils in ethanolic solution and triclosan mouthwashes. Environ Res. 2014;132:140-5.

47. Wiegand I, Hilpert K, Hancock REW. Agar and broth dilution methods to determine the minimal inhibitory concentration (MIC) of antimicrobial substances. Nat Protoc. 2008;3:163-75.

48. Veldhuizen EJ, Tjeerdsma-van Bokhoven JL, Zweijtzer C, Burt SA, Haagsman HP. Structural requirements for the antimicrobial activity of carvacrol. J Agric Food Chem. 2006;54:1874-9.

49. Viuda-Martos M, Mohamady MA, Fernandez-Lopez J, Abd El Razik KA, Omer EA, Perez-Alvarez JA. In vitro antioxidant and antibacterial activities of essential oils obtained from Egyptian aromatic plants. Food Control. 2011;22:1715-22.

50. Al-Thobity AM, Al-Khalifa KS, Gad MM, Al-Hariri M, Ali AA, Alnassar T. In vitro evaluation of the inhibitory activity of thymoquinone in combatting Candida albicans in denture stomatitis prevention. Int J Environ Res Public Health. 2017;14:743.

51. Koo H, Rosalen PL, Cury JA, Park YK, Bowen WH. Effects of compounds found in propolis on Streptococcus mutans growth and on glucosyltransferase activity. Antimicrob Agents Chemother. 2002;46:1302-9.

52. Smullen J, Koutsou GA, Foster HA, Zumbé A, Storey DM. The antibacterial activity of plant extracts containing polyphenols against Streptococcus mutans. Caries Res. 2007;41:342-9.

53. Erland LA, Bitcon CR, Lemke AD, Mahmoud SS. Antifungal screening of lavender essential oils and essential oil constituents on three post-harvest fungal pathogens. Nat Prod Commun. 2016;11:523-7.

Publisher's Note Springer Nature remains neutral with regard to jurisdictional claims in published maps and institutional affiliations. 